International Journal of Child, Youth and Family Studies (2016) 7(1): 27-44

\title{
CORPORAL PUNISHMENT OF CHILDREN IN THE JAMAICAN CONTEXT
}

\author{
Delores E. Smith
}

\begin{abstract}
Research literature has shown that violence against children poses a serious threat to public health and exacts a profound toll on society overall. However, corporal punishment continues to be used extensively in many countries despite the United Nation's call for its prohibition in all contexts in member states. Notwithstanding the significant progress Jamaica has made in advancing the rights of children, it is one of the member states in which corporal punishment remains pervasive. The purpose of the current article is to review the literature on the prevalence and scope of corporal punishment of children in the Jamaican context. In addition to presenting information on corporal punishment and its consequences, the article discusses the prevailing cultural dynamics and the debate surrounding the issue. Further, the article proposes strategies for addressing existing child socialization norms and beliefs about the efficacy of corporal punishment and offers suggestions to stakeholders regarding workable approaches to limiting the potential adverse outcomes for children and for society. It is presumed that legislative, educational, and media endeavors will be beneficial to reducing the incidence of corporal punishment of children in Jamaica.
\end{abstract}

Keywords: Jamaica, physical discipline, corporal punishment, violence against children

Acknowledgment: The author acknowledges the support of Geoffrey Mabe for his assistance with the literature search for this manuscript.

Delores E. Smith, Ph.D., is an Associate Professor in the Department of Child and Family Studies, College of Education, Health, and Human Sciences, 1215 W. Cumberland Ave., Knoxville, TN 37996. E-mail: delsmith@utk.edu 
International Journal of Child, Youth and Family Studies (2016) 7(1): 27-44

Physical violence against children is both a public health concern and a breach of children's human rights. Prevalence data have indicated that across the globe many children continue to be subjected to violence. The data also show that physical violence is the leading cause of injury and death among children (Pinheiro, 2006; UNICEF, 2013a; UNICEF, 2014). In many cases, children are victimized in the settings that would be expected to be safe havens for them, such as homes and schools, and by people in positions of trust (Pinheiro, 2006; UNICEF, 2010; UNICEF, 2014). Annually, an estimated one billion children between the ages of 2 and 14 across the globe are subjected to violent discipline by their caregivers on a regular basis (UNICEF, 2014). Equally troubling is the fact that despite the overwhelming data on the harmful effect of physical violence against children and the almost universal ${ }^{1}$ consensus amongst governments that all forms of violence against children should be forbidden, its incidence remains high and is, in fact, rising (UNICEF, 2006; UNICEF, 2013a; UNICEF, 2014).

The purpose of the current article is to provide a review of the prevailing literature on the prevalence and scope of violence against of children in the Jamaican context. However, the broad range of violence against children is beyond the scope of this article; therefore, the focus here is on physical discipline — corporal punishment — and its consequences for child developmental outcomes and society in general. Psychological aggression is also included because it always accompanies physical discipline (Pinheiro, 2006; UNICEF, 2006; UNICEF, 2014). In addition, strategies for addressing prevailing social norms about the efficacy of violent discipline in child rearing are presented and suggestions are made regarding workable approaches to limiting the deleterious outcomes for children and society.

\section{Scope of Physical Violence Against Children}

The United Nations (UN) defines physical violence against children as “all corporal punishment and all other forms of torture, cruel, inhuman or degrading treatment or punishment as well as physical bullying and hazing by adults or by other children. 'Corporal' (or 'physical') punishment is defined as any punishment in which physical force is used and intended to cause some degree of pain or discomfort, however light.” (UNICEF, 2014, p. 4). According to some sources (e.g., Pinheiro, 2006; UNICEF, 2006; UNICEF, 2014), corporal punishment of children is endemic in all societies regardless of their level of development and its prevalence is markedly higher than official published rates. A report by the Global Initiative to End all Punishment against Children (2013), indicated that almost all (94.6\%) of the world's children are legally not fully protected from corporal punishment in the home and $53 \%$ are not legally protected in schools. According to a United Nations (2006) report, between $80 \%$ and $98 \%$ of children are physically punished in their homes, mostly with the use of implements such as sticks, belts, and canes (Pinheiro, 2006). Furthermore, corporal punishment is standard practice in schools in many societies and in many countries juveniles in the justice system are sentenced to whipping and caning (Pinheiro, 2006).

\footnotetext{
${ }^{1}$ The Convention on the Rights of the Child is ratified by all countries except the United States.
} 
International Journal of Child, Youth and Family Studies (2016) 7(1): 27-44

Across the globe, many caregivers consider corporal punishment an acceptable and desirable feature of the child socialization process and readily provide justification for its use. However, most child development scholars and practitioners disapprove of any kind of physical discipline on the grounds that all physical punishment, however mild or infrequent, carries a built-in risk of escalation and abuse. Moreover, there is strong agreement that its use is ineffective in bringing about sustained desired behavior (Gershoff, 2002; Gelles \& Straus, 1979; UNICEF, 2006; UNICEF, 2014).

\section{The Jamaican Context}

Jamaica, the largest of the English-speaking Caribbean islands, is an independent nation whose population of about 2.8 million is mainly (92\%) of African descent. The median age is 24.9 years with children and youth aged 0 to 24 representing half (50.13\%) of the population (CIA World Factbook, 2015). In the context of the UN, Jamaica is situated within the Latin American and Caribbean region and classified as an upper middle income economy with a Human Development Index of .73 (United Nations Development Programme [UNDP], 2012). According to several UN reports (e.g., UNICEF, 2006; UNDP, 2012), despite the country's economic struggles, it has made good progress towards many of its National Millennium Development Goals and scored well on several social indicators of well-being. For example, the country boasts a life expectancy of 73.4 years, a literacy rate of $87 \%$, and a decent standard of living (UNICEF, 2006; UNDP, 2012). The country is a signatory to and has ratified the UN Convention on the Rights of the Child. Further, the country is a signatory to the UN Millennium Declaration and the World Fit for Children Declaration and Plan of Action, a commitment towards which the government has made steady progress (Statistical Institute of Jamaica \& UNICEF, 2013). However, despite its favorable showing in selected areas of development, major social challenges are evident. The country has one of the highest homicide rates in the world and the highest number of youth convicted of crime in the Caribbean region (UNDP, 2012), with concomitant negative effects on the wellbeing of children and society in general.

According to several sources (e.g., CIA World Factbook, 2015; UNDP, 2012; UNICEF, 2006), the high incidence of violence is Jamaica's most debilitating challenge, and children and youth are increasingly affected as witnesses, victims, and perpetrators. As victims, violence is the leading cause of death in the 15 to 24 age cohort of Jamaican males (Ward, Hutchinson, Levy, \& Ashley, 2011). Crime and violence statistics show that in 2010, children and youth aged 10 to 19 represented $25.3 \%$ of all intentional injuries treated at local hospitals, $27.4 \%$ of all stab wound cases, $42 \%$ of attempted suicides, and $68 \%$ of victims (primarily girls) of sexual assaults (UNICEF, n.d.). In 2012, Jamaican child welfare authorities received 8,726 reports of child abuse (almost 1,000 cases above the previous year) and 16 children were murdered in the first four months of 2013 (McFadden, 2013). The problems are believed to be much more widespread than even these numbers indicate, because violence against children is significantly underreported (UNICEF, 2006; UNICEF, 2014).

As perpetrators of violence, youth aged 15 to 24 are responsible for more than $50 \%$ of all major crimes (Ward et al., 2011). In 2010, 815 children and youth aged 12 to 19 were arrested for violent crimes such as murder, rape, robbery, wounding, and possession of firearms; 89\% of those crimes were committed by youth aged 15 to19 (UNICEF, n.d.). Over 4,000 children and 
International Journal of Child, Youth and Family Studies (2016) 7(1): 27-44

youth (primarily boys) of the 15 to 19 age cohort were brought before the courts for various offences in 2012 (UNICEF, 2013b). Children and youth are also witnesses to the commission of violence across all the major social institutions including domestic violence, corporal punishment at home and in school, and violence in the wider community and media. It has been suggested that the cumulative effect of exposure to violent experiences has desensitized children and led them to believe that violence is acceptable and normal (UNICEF, 2006; UNDP, 2012; UNICEF, 2014).

The elevated rates of youth crime have provoked speculation about the etiology of the problem in Jamaican society. Many have pointed to economic issues and their attending social maladies; others implicate an entrenched "culture of violence" to which children are exposed, particularly the violent discipline meted out to children in a variety of societal contexts (UNICEF, 2006; UNDP, 2012; Smith \& Mosby, 2003; Ward et al., 2011). The following section summarizes the resulting public debate on the use of corporal punishment.

\section{The Corporal Punishment Debate}

In Jamaica, attempts to explain the acceptance of corporal punishment have focused on child socialization practices within what is characterized as a "culture of beating children" (Smith \& Mosby, 2003). Several sources (e.g., Smith \& Mosby, 2003; UNICEF, 2013b; Ward et al.,, 2011) blame Jamaica's harsh childrearing tradition on its British colonial past, a history that included slavery and brutal punishment (Smith \& Mosby, 2003; UNDP, 2012; World Bank, 2003). However, while acknowledging the historical context, family professionals and child advocates have bemoaned the ubiquity of corporal punishment of children in contemporary times and have called for its abolition (Ward et al., 2011) ; UNDP, 2012; UNICEF, 2006; Global Initiative, 2015a). Child advocates are frustrated that the UN's specific directive to outlaw corporal punishment in all sectors of Jamaican society has not been realized (Global Initiative, 2015a; Niles, 2008). However, the UN’s edict has at least served to intensify the debate between opponents and supporters of the corporal punishment of children.

Armed with the latest research on the adverse effects of violent discipline on child outcomes, opponents of corporal punishment have argued that "violence begets violence" and that the perpetration and acceptance of the practice in children's proximal environments teach them that violence is an effective and legitimate problem-solving strategy (Smith \& Mosby, 2003; UNICEF, 2006; UNDP, 2012). Furthermore, they have pointed to research (e.g., Afifi, Mota, Dasiewicz, MacMillan, \& Sareen, 2012; Gershoff, 2002; Lansford et al., 2007; Middlebrooks \& Audage, 2008; Widom, Marmorstein, \& White, 2006) indicating that serious psychosocial problems in children are invariably preceded by exposure to violence, particularly corporal punishment. For example, Professor Paulo Sérgio Pinheiro, author of the UN's Global Report on Children and Violence, in an address to the Jamaican parliament warned that, "In an environment where violence breeds more violence, the ways in which Jamaican children are subjected to violence are inextricably linked to the unrelenting levels of crime and violence affecting the island” (Niles, 2008, para. 4). Further, Pinheiro reminded the Jamaican government that "No form of violence, however light, is acceptable under international law.... If we want to protect children from all kinds of violence we must have clear and objective laws prohibiting the use of violence in all situations, including inside homes and schools” (Niles, 2008, para. 7). 
International Journal of Child, Youth and Family Studies (2016) 7(1): 27-44

Defenders of corporal punishment regard it a necessary tool for proper child rearing, and the most effective deterrence to indiscipline in childhood and even afterwards. They view the Jamaican government's recent efforts to curtail the practice in schools as a serious miscalculation. For instance, one prominent politician has warned that the Ministry of Education's charge to teachers to cease the use of corporal punishment in schools is a "grave error" that will engender "assassins of the future" (Flemming, 2013, para. 8). Supporters also often cite a biblical maxim, "Spare the rod and spoil the child", in support of their position (Smith \& Mosby, 2003; UNICEF, 2006; UNICEF, 2014). They may offer themselves as examples of successful citizens who were not harmed by the corporal punishment they received as children (UNICEF, 2006). Moreover, proponents of corporal punishment draw support from research challenging the validity of information about the adverse effects of physical punishment on optimal child development. For example, some relevant research (e.g., Larzelere, Cox, \& Smith, 2010; Paolucci \& Violato, 2004) has found no evidence that spanking increased children's susceptibility to developmental problems and antisocial behaviors. Opponents of corporal punishment in Jamaica counter that spanking as such is rare in the Jamaican context. For example, Smith and Mosby (2003) noted that what is considered normative corporal punishment in Jamaica would warrant charges of physical abuse in many other countries. The following sections delineate the specific contexts in which Jamaican children are subjected to corporal punishment, also referred to as "physical punishment" or "violent discipline” in the literature. This article follows the usage of the source when reviewing the literature below.

\section{The Contexts of Corporal Punishment}

Gelles and Straus (1979) maintained that, outside of the police and military, the family is the most violent social group and the home the most violent context in society. In Jamaica, as is the case globally, harsh physical punishment is the most common form of discipline against children in the home (Global Initiative, 2015a; Smith \& Mosby, 2003; Ward et al., 2011) and its widespread use across boundaries of social status, family structure, and geographic location (rural versus urban) has been confirmed (Hamilton, 2010; Smith \& Mosby, 2003; UNICEF, 2006; UNICEF, 2010). For example, data from the Multiple Indicator Cluster Survey program (MICS) carried out from 2005 to 2006 showed that 89\% of Jamaican children aged 2 to 14 years experienced some form of violent discipline, either physical or psychological, from a primary caregiver in the month prior to data collection (UNICEF, 2010). Boys and girls were equally likely to experience physical punishment (e.g., being slapped, spanked, hit with an implement) and the same applies to psychological aggression. A small minority (7\%) of parents indicated that they used non-violent discipline exclusively. According to findings from international data (e.g., UNICEF, 2014), many children are subjected to corporal punishment even when their caregivers do not think it is a necessary form of discipline. In Jamaica, a minority (33\%) of caregivers indicated that physical punishment was necessary for proper childrearing, but the overwhelming majority (77\%) employed it as a disciplinary measure.

Follow-up data from MICS4 2010/2011 (Statistical Institute of Jamaica \& UNICEF, 2013) showed a slight decline (5\%) in the occurrence of any form of violent discipline in the same age cohort of children. In the more recent data, $84.5 \%$ of children experienced any violent discipline; 68.4\% were physically punished, 71.9\% experienced psychological aggression, and $27 \%$ of parents viewed physical punishment as a necessity. However, there was a $3 \%$ increase in the percentage of caregivers (9.9\%) who indicated that they used non-violent discipline 
exclusively. In the latter survey boys were more likely than girls to experience physical discipline (71.4\% vs. 65.2\%) and were subjected to more severe punishment. Evidence from a study of childrearing in 24 developing countries showed that Jamaican caregivers registered the highest prevalence (84\%) of administering physical punishment to their children under 5 years in response to children's perceived misbehavior (Lansford \& Deater-Deckard, 2012). A government survey assessing Jamaican adults' attitudes toward the use of corporal punishment indicated that the majority (56\%) of Jamaicans believed that "beating" a child was necessary to correct bad behavior. However, nearly two-thirds (64\%) of respondents indicated that they would abandon the use of corporal punishment if their children obeyed them (Hamilton, 2010).

Despite the UN's call for a universal ban on corporal punishment in schools among member states, 72 countries, including Jamaica, still have not fully prohibited its use in that context (Global Initiative, 2015b). According to the United Nations Children's Fund (UNICEF, 2006), violence in schools is most often directed at students through physical punishment and psychological abuse (e.g., humiliation, intimidation) by teachers. In Jamaica, as in many societies, corporal punishment of children in school is used not only as a disciplinary measure but as a pedagogical strategy (Flemming, 2013; Global Initiative, 2015a; Smith \& Mosby, 2003). For example, one principal defended the practice on pedagogical grounds by explaining that the "flogging of students plays a key rule (sic) in ensuring that they [children] focus and display the behaviours that are conducive to learning” (Hamilton, 2012, para. 2). In a survey of 11- to 12year-old children, 75\% reported being beaten with an object by teachers (Samms-Vaughan, Jackson, Ashley, \& Lambert, 2000) and 80\% of the teachers in another Jamaican study reported that they often used corporal punishment to discipline children (Pottinger \& Nelson, 2004). Jones and Brown (2008) noted that $81 \%$ of Jamaican teachers in one study admitted to using implements such as a belt, strap, or board to hit children, and students equated the punishment they received at school to the punishment they received at home.

Officially, corporal punishment is already banned in Jamaican early childhood settings serving children under the age of six years and in alternative care settings, such as schools for children in conflict with the law, but remains legal in other educational institutions (Flemming, 2013; Global Initiative, 2015a). In 2009, citing corporal punishment as a breach of the United Nations Convention on the Rights of the Child, the Ministry of Education issued an order to suspend the practice across the education system (Flemming, 2013). However, not surprisingly, the order has met with stiff opposition from many stakeholders including parents, teachers, and policy makers. Indeed, even where the practice is legally prohibited (i.e., daycare and alternative care settings), policies are ignored and the corporal punishment of children continues, openly in some environments and surreptitiously in others (Global Initiative, 2015a; Grant, Morris, \& Gibson, 2011; UNDP, 2012).

The momentum that sustains the corporal punishment of children in Jamaican life extends into the justice system. In Grant, Morris, and Gibson’s 2011study of children's experiences with the Jamaican justice system, they found serious non-compliance with the law, as set out in the 2004 Jamaica Child Care and Protection Act (CCPA), requiring children in residential facilities to be free from corporal punishment. In that study, children in conflict with the law ${ }^{2}$ reported

${ }^{2}$ Defined by UNICEF as anyone under age 18 who comes into contact with the justice system as a result of being suspected or accused of committing an offence. 
International Journal of Child, Youth and Family Studies (2016) 7(1): 27-44

harsh treatment by the police, including physical and emotional abuse. Children also reported similar treatment by the staff of residential facilities; those reports were confirmed by practitioners in the field. It is instructive that the majority of children who come in conflict with the law are not violent offenders but children in need of "care and protection following abuse, neglect, or abandonment” (UNDP, 2012, p. 46).

\section{Conceptualization of Corporal Punishment}

The relevant literature is inconsistent in its use of terms such as corporal punishment, violent or physical discipline, and physical abuse. There is also much irregularity on how those concepts are operationalized (e.g., spanking vs. beating, mild vs. harsh, discipline vs. abuse) and this has led to the terms being used to some extent interchangeably. However, there is disagreement regarding whether the interchangeable use is functional. On the one hand, there is general agreement among many social scientists that physical punishment and physical abuse fall along the same continuum of undesirable family violence; that most physical child abuse emanates from physical discipline; and that, therefore, it is meaningless to draw a distinction between mild physical punishment and physical abuse (Gelles \& Straus, 1979; Gershoff, 2002; UNICEF, 2006; Straus \& Paschall, 2009; UNICEF, 2014). Furthermore, many scholars have argued that for physical punishment to be "effective" (i.e., temporarily halt the perceived misbehavior), it has to be administered increasingly more severely; thus, a mild swat on the buttocks will likely escalate into a cycle of abuse (McKenzie, Nicklas, Waldfogel, \& BrooksGunn, 2012; UNICEF, 2014).

In one study (McKenzie et al., 2012), long-term behavioral problems were found to be associated with spanking in children in a vicious circle: spanking increased children's externalizing behavior which in turn predicted parental spanking. Contrarily, some researchers (e.g., Baumrind, Larzelere, \& Cowan, 2002; Paolucci \& Violato, 2004), have insisted that spanking be differentiated from abuse and conceptualized accordingly. For example, Paolucci and Violato (2004) defined spanking as physically non-injurious discipline administered with the intention of modifying the child's behavior. This is in contrast to physical abuse which denotes severe actions such as slapping the face, beating, choking, or other repeated demoralizing treatment. Further, some research studies (e.g., Larzelere et al., 2010; Paolucci \& Violato, 2004) have shown that non-abusive physical punishment can be beneficial to child outcomes or at the very least have no significant risk for adverse child development. Those researchers suggest that it is inept parenting and physical abuse that put children at risk for detrimental outcomes, not corporal punishment per se (Baumrind et al., 2002; Larzelere et al., 2010). Moreover, they have hypothesized that there might be variance in development outcomes as a function of the context in which the punishment is delivered. For instance, battered children may have worse outcomes than children who are spanked mildly. Further, children's misbehaviors may elicit a variety of parental corrective measures such as verbal correction, privilege removal, and ignoring. These alternative disciplinary measures may confound the analysis of outcomes, obscuring the effects from corporal punishment alone (Larzelere et al., 2010). In contrast, Holden (2002), while admitting the flaws in many studies of corporal punishment and child outcomes, has concluded that there is enough empirical evidence to indicate that "corporal punishment does no good and may even cause harm” (p. 594). 
International Journal of Child, Youth and Family Studies (2016) 7(1): 27-44

\section{Consequences of Corporal Punishment}

Despite some conflicting findings and ongoing controversy regarding the effect of corporal punishment on child outcomes, the preponderance of the research literature has indicated that victims of corporal punishment suffer both short- and long-term developmental difficulties. This has led many child development scholars to question the efficacy of corporal punishment (Harford, Yi, \& Grant, 2014; McKenzie et al., 2012; Widom et al., 2006). Furthermore, the research on the harmful effects of corporal punishment is so robust that, as of September, 2015, 46 countries had abolished all corporal punishment of children in all settings and 126 have outlawed its use in schools (Global Initiative, 2015b). According to Holden (2002) “...the weight of the available evidence, as well as theory, is clearly on the side of the negative effects of customary corporal punishment” (p. 595).

Gershoff's (2002) seminal meta-analysis of 88 studies on the effects of corporal punishment of children revealed that although physical discipline induced immediate compliance by the child, it engendered problematic outcomes such as decreased rates of internalization of morals and values, maladaptive socioemotional functioning, poor parent-child relationship, and increased short- and long-term aggression. In addition, physical punishment was linked to delinquency and other antisocial conduct, increased risk of subsequent victimization, the perpetuation of the cycle of violence by victimizing one's own children or spouse, and increased likelihood of involvement in criminal behavior. In another study, preschoolers who had ever been smacked by their primary caregiver in the first 22 months of life were twice as likely to exhibit emotional and behavioral problems as their peers who were never smacked (Scott, Lewsey, Thompson, \& Wilson, 2014). Compared to the control group, children who were physically punished were one and a half times more likely to use illicit drugs and have drug related problems in adulthood (Widom et al., 2006). Also, child victims of corporal punishment were found to be at greater risk for dropping out of high school, teen parenthood, being arrested as juveniles (Lansford et al., 2007), interpersonal aggression, low self-esteem, and suicidal behaviors and other psychiatric disorders (Afifi et al., 2012; Harford et al., 2014; Middlebrooks \& Audage, 2008; Smith, Springer, \& Barrett, 2011). In a study by Felson and Lane (2009), inmates who reported experiencing childhood physical abuse (inmates' subjective assessment of abuse) were more likely to commit violent offenses, such as homicide, robbery, and sexual assault, than nonviolent offenses.

Neuropsychological research and neuroimaging studies have indicated an association between corporal punishment and adverse cognitive and psychosocial development. Although the exact pathway is unclear, researchers have indicated that physical punishment produces detrimental effects on the trajectories of brain development. In one study (Tomoda et al., 2009), children who experienced harsh corporal punishment (operationalized as being spanked at least once per month for more than three years) had a lower volume of grey matter in the prefrontal cortex, the region of the brain associated with such cognitive abilities as decision making, sensorimotor functioning, mental health, and overall intelligence. Straus and Pachall (2009) reported that mothers' use of corporal punishment (slapping or hitting with an object) in children aged two to four years old was independently related to decreased cognitive ability relative to other children who received little or no spanking. Specifically, “The more CP [corporal punishment] experienced, the more they fell behind children who were not spanked” (p. 459). In another study, a mother spanking her three-year-old child more than twice in the previous month 
International Journal of Child, Youth and Family Studies (2016) 7(1): 27-44

was correlated with higher levels of aggression at age 5. (Taylor, Manganello, Lee, \& Rice, 2010).

It is noteworthy that many of the psychosocial outcomes of corporal punishment noted here have been reported in the limited research done in Jamaica. In the study by Smith et al., corporal punishment was associated with adverse psychological and behavioral consequences (2001). Compared to the control group, adolescents who reported being victims of corporal punishment (being slapped or hit with objects) also indicated a greater propensity to developmental adjustment problems including alcohol and drug use, anxiety, depression, and suicidal ideation. Global data have also shown that high levels of exposure to violence at home and school independently predicted childhood aggression (UNICEF, 2006). However, a major criticism of many studies that show detrimental effects of corporal punishment is that they often do not take potentially confounding variables into account. For example, factors such as marital discord, stress pile-up, and a family history of antisocial behaviors are customarily omitted in those studies (Paolucci \& Violato, 2004).

Various sequelae of negative physical health outcomes in adulthood have been linked to physical punishment in childhood. These include cardiovascular diseases, arthritis, obesity (Afifi, Mota, MacMillan, \& Sareen, 2013; Fuller-Thomson, Brennenstuhl, \& Franck, 2010), and general poor health (Middlebrooks \& Audage, 2008; Springer, 2009). However, except for direct physical injury, the connections are unclear. Some researchers (e.g., Fuller-Thomson et al., 2010; Springer, 2009) have hypothesized the link to be a product of the coping mechanisms used by victims to alleviate the stress brought on by the violent experiences and which in turn drive poorer health status. For instance, stressful childhood experiences have been shown to increase the risk of poor health behaviors in adulthood and health risk behaviors have been implicated as the main conduits through which cardiovascular diseases occur (Fuller-Thomson et al., 2010; Springer, 2009). Springer (2009), using a multi-pathway life course model, delineated smoking and substance use as key pathways connecting childhood physical abuse to respiratory problems such as bronchitis and emphysema; mental health problems to ulcers; and Body Mass Index and mental health to general physical health. In that study physical abuse was operationalized as the frequency (some or a lot) at which the child had been slapped, shoved, or had things thrown at him or her before age 17 by a parent or guardian.

For society, the direct and indirect economic and social costs of violence against children are high. Direct costs include short- and long-term medical care for injuries, mental health services and treatment for survivors, and the cost to the justice system. Indirect costs are the less conspicuous ones such as the loss of potential human capital, reduced productivity, and decreased quality of life. Worldwide, the financial burden of all kinds of violence against children is conservatively estimated at US \$7 trillion - about 8\% of the world's gross domestic product (GPD) (Pereznieto, Montes, Routier, \& Langston, 2014). In the United States, the lifetime cost of child abuse to society is about US \$124 billion annually (Fang, Brown, Florence, \& Mercy, 2012). A search of the literature showed no specific data on the cost of violence against children in Jamaica; however, extrapolating from estimates of expenditures on violence in general is instructive. In 2006, the annual direct and indirect cost of interpersonal violence amounted to an estimated $\$ 29.6$ billion Jamaican dollars. Direct medical cost alone averaged $12 \%$ of the total health expenditure of the country; loss of productivity due to interpersonal violence related injuries accounted for approximately $160 \%$ of the total health expenditure or $4 \%$ 
International Journal of Child, Youth and Family Studies (2016) 7(1): 27-44

of the country's GDP (Butchart et al., 2008). One source (UNDP, 2012) estimated that Jamaica spends more than US \$529 million annually to fight youth violence and loses another US\$99.3 million in potential investment revenue.

\section{Strategies for Prevention and Intervention}

Once physical violence against children is accepted as a serious problem, the continued high prevalence of harsh corporal punishment in Jamaican homes and schools strongly suggests the need for action at the national level. Most relevant scientific research has shown evidence of a strong link between physical punishment and child adjustment problems. Therefore, strategies to respond to the practices that promote problematic development are imperative. Global studies on the cost of violence against children have confirmed that violence is a major drain on national economies and that the best approach to addressing the problem is prevention. For instance, pertinent data from Europe reveal that every euro spent on protecting children from any kind of violence produces a social return of 87 euros (UNICEF, 2013a), an indication that the consequential cost is significantly higher than the preventative investment (Pereznieto et al., 2014; UNICEF, 2013a). For countries with developing economies, like Jamaica, implementing programs and services can be a major economic challenge. Nonetheless, those societies will need to weigh the cost of protecting children from violence and abuse against the benefits of a stable, healthy, and productive citizenry, and the implications of these for national development and prosperity.

Any effort to address caregiver violence against children in Jamaica would necessitate a dramatic cultural shift and major social change in norms, beliefs, and attitudes regarding child socialization practices. The task may not be as daunting as it seems initially, since the admittedly scant literature suggests that many Jamaicans would be amenable to considering alternatives to violent disciplinary practices. As noted earlier, two-thirds of Jamaicans indicated their willingness to abandon the use of corporal punishment if their children would obey (Hamilton, 2010; UNICEF, 2006). Moreover, many parents indicated their familiarity with and use of positive child discipline techniques (e.g., showing affection to the child, withdrawing privileges, using time outs), and expressed a strong desire for training in child behavior management (Baker-Henningham, 2011). An obvious discrepancy between that knowledge and practice exists: despite parents' general agreement that corporal punishment was neither desirable nor effective, they reportedly used the practice anyway (Baker-Henningham, 2011; UNICEF, 2014). Therefore, a communal shift in child socialization would require a concerted multisectoral and multifaceted approach and the collective effort of stakeholders at all levels: parents, family, community, and government (UNICEF, 2006; United Nations, 2009; UNICEF, 2014). Programs and services that promote positive caregiver-child relationships are desirable and serve both prevention and intervention purposes. The following sections outline specific areas for consideration as approaches to addressing current harsh disciplinary childrearing practices in Jamaica.

Laws and policies. A positive first step toward reducing harsh childrearing practices would be for the government to implement legal reforms in accordance with the UN's mandate to outlaw corporal punishment in all settings in Jamaica. According to UNICEF (2010), the prohibition of violence against children in all contexts sends a clear and resolute message to 
society that such violence is unacceptable and intolerable. However, the Jamaican government has resisted banning corporal punishment of children in the home, perhaps because of perceived opposition, particularly from those who hold the view that it is the parents' prerogative to discipline their children however they see fit (UNICEF, 2006). Nonetheless, the government has already taken some steps toward reducing the occurrence of corporal punishment of children by prohibiting the practice in some settings. Furthermore, the government has indicated its intention to outlaw the practice in all educational settings (Global Initiative, 2015a). Regrettably though, even within contexts where the practice is legally prohibited, such as daycare, policies are poorly enforced (Global Initiative, 2015a; Grant, Morris, \& Gibson, 2011; UNDP, 2012). Proper enforcement of these existing laws is another necessary step towards fulfilling the UN's mandate to implement laws that protect all children from corporal punishment (Global Initiative, 2015a; UNICEF, 2013a; UNICEF, 2014).

Once legal reforms are instituted, intensive ongoing public service and mass media campaigns to raise awareness and build support among the public must be undertaken. Both the detrimental effects of corporal punishment and the positive consequences of non-violent methods of discipline must be emphasized. Media campaigns have been shown to be effective in changing public behavior (Evans et al., 2006; UNICEF, 2014). They should be complemented with nationwide comprehensive training programs for professionals who work with and for children; for parents, families, and caregivers; and for children themselves. According to the UN (UNICEF, 2014), a real cultural shift in attitudes towards violence against children must occur at two levels: "On the government side, a solid legal framework must be instituted, implemented and monitored; on the part of each citizen, an effort must be made to drive change on a daily basis” (p. 170).

Professional education and training. Policy makers, teachers, and other professionals (e.g., social workers, health professionals, clergy, law enforcement personnel) should be targeted for special ongoing training in child behavior management. Since corporal punishment is a culturally-sanctioned practice, it is likely that professionals themselves may not be aware of what constitutes child abuse or may not be adequately skilled to detect it. Govender and Sookrajh (2014) found that 18 years after the abolition of corporal punishment in South African schools, teachers were still confused about what constitutes appropriate and acceptable discipline. Therefore, professionals in similar situations should be provided with and directed through workable models of alternative discipline since they will be obliged to teach the requisite skills to community stakeholders. Another issue related to professionals' skill sets is understanding the rights of the child as laid out by the UN Convention on the Rights of the Child. It has been confirmed that professionals for the most part are inadequately educated on children's rights (Global Initiative, 2015a), indicating a need to promote greater public understanding of the content and purpose of that UN treaty.

Clergy and religious leaders are particularly critical to the fight against the corporal punishment of children. Because those leaders are trusted and authoritative members of local communities, they can play a pivotal role in persuading their congregants to change their childrearing behaviors. An estimated $76 \%$ of Jamaicans are affiliated with a religion; of those, $70 \%$ are Christian (CIA World Factbook, 2015). However, considering that many clergy hold steadfastly to and promote corporal punishment as a divine mandate, an especially resolute effort to get religious denominations to join forces in combating harsh discipline may be required. 
International Journal of Child, Youth and Family Studies (2016) 7(1): 27-44

Indeed, there has been increasing religious support worldwide for the UN's Declaration on Violence against Children through The Kyoto Declaration (Religions for Peace, 2006) but locally, strong and decisive opposition to corporal punishment has been slow (UNICEF, 2006).

Family programs and services. Providing families with positive child guidance techniques can help mitigate the risk of harsh discipline and the undesirable outcomes that accompany corporal punishment (Holden, 2002; UNICEF, 2014). Therefore, family skills training programs should be key components of any effort to curb the practice. Indeed, a strong body of literature has demonstrated the efficacy of such programs and services in preventing and alleviating harmful family interactions. For example, an evaluation of family skills training across the globe has indicated that those programs, in addition to being cost-effective, can "positively change family functioning and parent practices in enduring ways" (United Nations, 2009, p. 1). Research has also demonstrated that the most effective programs (a) were implemented before the targeted problem began (e.g., before children are born); (b) involved training for the whole family; (c) were overseen by trained professionals; and (d) were presented by trained professionals through regular home visitations or conducted at local community centers (UNICEF, 2014). The UN recommends intensive "home visiting services during late pregnancy and in the first few years of their child's life and/or extended parenting education workshops when the child begins pre-school” (UNICEF, 2006, p. 32). Positive parent-child interaction and child abuse prevention skills are particularly advantageous (UNICEF, 2014).

The fact that alternative methods of discipline tend to require significantly greater time and effort than does corporal punishment may lead caregivers to conclude that corporal punishment is more efficacious (Pinheiro, 2006; UNICEF, 2006, UNICEF, 2014). Additionally, many caregivers may be uninformed about the child development process and what behaviors are appropriate and normal at each developmental stage. Thus, it is conceivable that children are punished for what should be seen as routine development and conduct. Therefore, basic child development information coupled with elements of non-violent discipline should be emphasized in parent education programs. Taken together, parents and prospective parents should be educated on the investment of time and effort required for optimal child outcomes, made aware of the advantages of non-violent discipline, instructed on basic child development processes, and coached on alternative models to corporal punishment.

Research (e.g., McKenzie et al., 2012) has provided good evidence on the circular relationship between physical punishment and children's externalizing behavior: violent discipline predicted children's conduct problems which in turn increased children's likelihood of incurring physical punishment. One approach to protecting children from disciplinary violence is thus to help them acquire good social skills. Social skills competence has been shown to enhance emotional regulation, boost communication and problem solving skills, promote positive selfesteem, and lessen conduct problems (UNICEF, 2006). Such skills also enable children "to cope with violence and break the cycle of abuse” (UNICEF, 2014, p. 170).

In fact, researchers in one study (Baker-Henningham et al., 2012), pilot-tested a low-cost school-based intervention program to assess its effectiveness on Jamaican children's social skills and conduct problems. At the end of the intervention, parents and teachers reported significant improvement in social skills and behaviors among children who were exposed to the intervention. An additional positive outcome was children's improved school attendance. It would be prudent, therefore, for such programs to be introduced nationwide. Life skills and 
International Journal of Child, Youth and Family Studies (2016) 7(1): 27-44

social skills education can be subsumed in formal activities, such as school, and informal ones, such as sports (UNICEF, 2014). Additionally, children should know and understand their right to be protected from all kinds of violence. Hence, exercises geared toward helping children recognize violence against themselves and how to protect themselves from abuse should be a critical component of such training (UNICEF, 2006).

\section{Conclusion}

The preponderance of research literature on the corporal punishment of children finds a robust link between the practice and enduring adverse consequences in childhood and adulthood. In addition to the economic costs to society, the human toll — in terms of human capital and productivity, physical and mental health, and overall quality of life - cannot be calculated, but is surely unacceptable. The literature, therefore, has provided a persuasive argument in favor of encouraging caregivers to abandon the use of physical punishment. Clearly, Jamaica has made significant progress in advancing the rights of children; however, the disciplinary practices to which children are exposed on a daily basis urgently need to be addressed. Although a history of corporal punishment is not a guarantee that a child will suffer serious developmental impairment, the risk of problematic outcomes is increased. To guard against those risks, appropriate child protection laws must be enacted and enforced. In addition, public education and training of key stakeholders, which could be made available through ante-natal care clinics, community health care clinics, and parent-teacher associations, are needed to help shift entrenched cultural attitudes that condone violent disciplinary practices. This will require the concerted effort of all segments of society. 
International Journal of Child, Youth and Family Studies (2016) 7(1): 27-44

\section{References}

Afifi, T. O., Mota, N. P., Dasiewicz, P., MacMillan, H. L., \& Sareen, J. (2012). Physical punishment and mental disorders: Results from a nationally representative US sample. Pediatrics, 130(2), 184-192. doi:10.1542/peds.2011-2947

Afifi, T. O., Mota, N., MacMillan, H. L., \& Sareen, J. (2013). Harsh physical punishment in childhood and adult physical health. Pediatrics, 132, e333-e340. doi:10.1542/peds.2012$\underline{4021}$

Baker-Henningham, H. (2011). Transporting evidence-based interventions across cultures: Using focus groups with teachers and parents of pre-school children to inform the implementation of the Incredible Years Teacher Training Programme in Jamaica. Child: Care, Health and Development, 37, 649-661.

Baker-Henningham, H., Scott, S., Jones, K., \& Walker, S. (2012). Reducing child conduct problems and promoting social skills in a middle-income country: Cluster randomized controlled trial. British Journal of Psychiatry, 201(2), 101-108. doi:10.1192/bjp.bp.111.096834

Baumrind, D., Larzelere, R. E., \& Cowan, P. A. (2002). Ordinary physical punishment: Is it harmful? Comment on Gershoff (2002). Psychological Bulletin, 128, 580-589.

Butchart, A., Brown, D., Khanh-huynh, A., Corso, P., Florquin, N., \& Muggah, R. (2008). Manual for estimating the economic costs of injuries due to interpersonal and self-directed violence. Geneva, Switzerland: World Health Organization.

CIA World Factbook. (2015). Jamaica. Retrieved from https://www.cia.gov/library/publications/the-world-factbook/geos/jm.html

Evans, A. E., Dave, J., Tanner, A., Duhe, S., Condrasky, M., Wilson, D., ... Evans, M. (2006). Changing the home nutrition environment: Effects of a nutrition and media literacy pilot intervention. Family \& Community Health, 29, 43-54.

Fang, X., Brown, D. S., Florence, C. S., \& Mercy, J. A. (2012). The economic burden of child maltreatment in the United States and implications for prevention. Child Abuse \& Neglect, 36(2), 156-165. doi:10.1016/j.chiabu.2011.10.006

Felson, R. B., \& Lane, J. (2009). Social learning, sexual and physical abuse, and adult crime. Aggressive Behavior, 35, 489-501.

Flemming, B. (2013, November, 23). 'Spare the rod, spoil the child.' Jamaica Gleaner Online. Retrieved from http://jamaica-gleaner.com/gleaner/20130608/western/western2.html

Fuller-Thomson, E., Brennenstuhl, S., \& Franck, J. (2010). The association between childhood physical abuse and heart disease in adulthood: Findings from a representative community sample. Child Abuse and Neglect, 34, 689-698. doi:10.1016/j.chiabu.2010.02.005 
International Journal of Child, Youth and Family Studies (2016) 7(1): 27-44

Gelles, R. J., \& Straus, M. A. (1979). Determinants of violence in the family. In W. R. Burr, R. Hill, F. Nye, \& I. Reiss (Eds.). Contemporary theories about the family (Vol. 1, pp. 549581). New York, NY: Free Press.

Gershoff, E. T. (2002). Corporal punishment by parents and associated child behaviors and experiences: A meta-analytic and theoretical review. Psychological Bulletin, 128(4), 539579.

Global Initiative to End All Corporal Punishment of Children. (2013). Global report: Ending legalised violence against children. London, England: Association for the Protection of All Children.

Global Initiative to End all Corporal Punishment of Children. (2015a). Corporal punishment of children in Jamaica. Retrieved from http://endcorporalpunishment.org/assets/pdfs/statesreports/Jamaica.pdf

Global Initiative to End all Corporal Punishment of Children (2015b). Countdown to universal prohibition. Retrieved from http://www.endcorporalpunishment.org/progress/countdown.html

Govender, D. S., \& Sookrajh, R. (2014). ‘Being hit was normal’: Teachers' (un)changing perceptions of discipline and corporal punishment. South African Journal of Education, 34(2), 1-17.

Grant, L., Morris, S., \& Gibson, C. (2011). A study of the profile of children in conflict with the law in Jamaica. Office of the Children's Advocate (Jamaica). Retrieved from http://www.welcome.oca.gov.jm/media/Children-in-Conflict-with-the-Law.pdf

Hamilton, P. (2010, February 17). Kicking kids is OK for most Jamaicans - Study. Jamaica Gleaner Online. Retrieved from http://jamaicagleaner.com/gleaner/20100217/lead/lead4.html

Hamilton, C. (2012, November 25). ‘At this school we slap kids’: Kensington Primary’s defence of corporal punishment angers some parents. The Jamaica Observer. Retrieved from http://www.jamaicaobserver.com/news/Kensington-Primary-s-defence-of-corporalpunishment-angers-some-parents

Harford, T., Yi, H., \& Grant, B. (2014). Associations between childhood abuse and interpersonal aggression and suicide attempt among U.S. adults in a national study. Child Abuse and Neglect, 38, 1389-1398. doi:10.1016/j.chiabu.2014.02.011

Holden, G. W. (2002). Perspectives on the effects of corporal punishment: Comment on Gershoff (2002). Psychological Bulletin, 128, 590-595.

Jones, J., \& Brown, A. (2008). Assessment of the Child Abuse Mitigation Project at the Bustamante Hospital for children. Retrieved from http://www.unicef.org/evaldatabase/files/CAMP_Bustamante_final_report-_Dec08.pdf 
International Journal of Child, Youth and Family Studies (2016) 7(1): 27-44

Langworthy, R. H., Barnes, A., \& Curtis, R. (1998). Results from the long-term inmate survey: Focus on child abuse histories. Report prepared for the Alaska Department of Corrections. Anchorage, AK: Justice Center, University of Alaska.

Lansford, J., Miller-Johnson, S., Berlin, L., Dodge, K., Bates, J., \& Pettit, G. (2007). Early physical abuse and later violent delinquency: A prospective longitudinal study. Child Maltreatment, 12, 233-245. doi:10.1177/1077559507301841

Lansford, J. E., \& Deater-Deckard, K. (2012). Childrearing discipline and violence in developing countries. Child Development, 83, 62-75.

Larzelere, R. E., Cox, R. B., \& Smith, G. L. (2010). Do nonphysical punishments reduce antisocial behavior more than spanking? A comparison using the strongest previous causal evidence against spanking. BioMed Central Pediatrics, 10, 1-17.

MacKenzie, M. J., Nicklas, E., Waldfogel, J., \& Brooks-Gunn, J. (2012). Corporal punishment and child behavioural and cognitive outcomes through 5 years of age: Evidence from a contemporary urban birth cohort study. Infant and Child Development, 21(1), 3-33. doi:10.1002/icd.758

McFadden, D. (2013, June 5). Jamaica’s ‘unrelenting violence’ against children condemned by UNICEF. The Toronto Star. Retrieved from http://www.thestar.com/news/world/2013/06/05/jamaicas_unrelenting_violence_against_c hildren_condemned_by_unicef.html

Middlebrooks, J. S., \& Audage, N. C. (2008). The effects of childhood stress on health across the lifespan. Atlanta, GA: Centers for Disease Control and Prevention, National Center for Injury Prevention and Control.

Niles, C. (2008, February 27). Violence against children high on the political agenda in Jamaica. Retrieved from http://www.unicef.org/jamaica/violence_11633.htm

Paolucci, E. O., \& Violato, C. (2004). A meta-analysis of the published research on the affective, cognitive, and behavioral effects of corporal punishment. The Journal of Psychology: Interdisciplinary and Applied, 138, 197-222. doi:10.3200/JRLP.138.3.197-222

Pereznieto, P., Montes, A., Routier, S., \& Langston, L. (2014). The costs and economic impact of violence against children: Child Fund Alliance Report. London, UK: Overseas Development Institute (ODI).

Pinheiro, P. S. (2006). World report on violence against children: United Nations study on violence against children. Geneva, Switzerland: United Nations.

Pottinger, A., \& Nelson, K. (2004). A climate of punishment in Jamaican classrooms: Attitudes, beliefs, and use of disciplinary practices by educators. Caribbean Journal of Psychology, 1, 22-38. 
International Journal of Child, Youth and Family Studies (2016) 7(1): 27-44

Religions for Peace. (2006). A multi-religious commitment to confront violence against children. Retrieved from http://srsg.violenceagainstchildren.org/sites/default/files/documents/docs/Kyotodeclaration2006.pdf

Samms-Vaughan, M., Jackson, M., Ashley, D., \& Lambert, M. (2000). Jamaican children's experience of corporal punishment at home and at school. Kingston, Jamaica: Report prepared by the University of the West Indies \& Ministry of Health, Jamaica.

Scott, S., Lewsey, J., Thompson, L., \& Wilson, P. (2014). Early parental physical punishment and emotional and behavioural outcomes in preschool children. Child: Care, Health and Development, 40(3), 337-345. doi:10.1111/cch.12061

Smith, D. E., \& Mosby, G. (2003). Jamaican child-rearing practices: The role of corporal punishment. Adolescence, 38, 370-381.

Smith, D. E., Springer, C. M., \& Barrett, S. (2011). Physical discipline and socioemotional adjustment among Jamaican adolescents. Journal of Family Violence, 26(1), 51-61.

Springer, K. W. (2009). Childhood physical abuse and midlife physical health: Testing a multipathway life course model. Social Science \& Medicine, 69, 138-146.

doi:10.1016/j.socscimed.2009.04.011

Statistical Institute of Jamaica (STATIN) and United Nations Children's Fund (UNICEF). (2013). Jamaica Multiple Indicator Cluster Survey 2011: Final Report. Kingston, Jamaica: STATIN \& UNICEF.

Straus, M. A., \& Paschall, M. J. (2009). Corporal punishment by mothers and development of children's cognitive ability: A longitudinal study of two nationally representative age cohorts. Journal of Aggression, Maltreatment and Trauma, 18, 459-483. doi:10.1080/10926770903035168

Taylor, C. A., Manganello, J. A., Lee, S. J., \& Rice, J. C. (2010). Mothers' spanking of 3-yearold children and subsequent risk of children's aggressive behavior. Pediatrics, 125, e1057e1065. doi:10.1542/peds.2009-2678

Tomoda, A., Suzuki, H., Rabi, K., Sheu, Y. S., Polcari, A., \& Teicher, M. H. (2009). Reduced prefrontal cortical gray matter volume in young adults exposed to harsh corporal punishment. Neuroimage, 47, 66-71. doi:10.1016/j.neuroimage.2009.03.005

UNICEF. (n.d.). The children: Protection. Retrieved from http://www.unicef.org/jamaica/children_1570.htm

UNICEF. (2006). Violence against children in the Caribbean region: Regional assessment. Panama, Republic of Panama: UNICEF Regional Office for Latin America and the Caribbean.

UNICEF. (2010). Disciplinary practices at home: Evidence from a range of low- and middleincome countries. New York, NY: Author. 
International Journal of Child, Youth and Family Studies (2016) 7(1): 27-44

UNICEF. (2013a). Toward a world free from violence: Global survey on violence against children. New York, NY: Author.

UNICEF. (2013b). Annual report 2013-Jamaica. Retrieved from http://www.unicef.org/about/annualreport/files/Jamaica_COAR_2013.pdf

UNICEF. (2014). Hidden in plain sight: A statistical analysis of violence against children. New York, NY: Author.

United Nations. (2006). Report of the independent expert for the United Nations study on violence against children. Retrieved from http://www.unicef.org/violencestudy/reports/SG_violencestudy_en.pdf

United Nations. (2009). Guide to implementing family skills training programmes for drug abuse prevention. Vienna, Austria: United Nations Office on Drugs and Crime.

United Nations Development Programme (UNDP). (2012). Caribbean human development report 2012: Human development and the shift to better citizen security. New York, NY: Author.

Ward, E., Hutchinson, D., Levy, H., \& Ashley, D. (2011). Youth violence in Kingston, Jamaica. In Social and economic costs of violence: Workshop summary from the Forum on Global Violence Prevention; Board on Global Health; Institute of Medicine; National Research Council. Washington, DC: National Academies Press. Retrieved from http://www.ncbi.nlm.nih.gov/books/NBK190004/

Widom, C., Marmorstein, N., \& White, H. (2006). Childhood victimization and illicit drug use in middle adulthood. Psychology of Addictive Behaviors, 20(4), 394-403.

World Bank. (2003). Caribbean youth development issues and policy directions. (A World Bank country study). Washington, D.C.: Author. 